\title{
Australian orchids and the doctors they commemorate
}

rchidaceae is the largest family of flowering plants. Orchids grow in habitats ranging from subalpine niches to the tropics, and they produce some of the most beautiful, varied and intriguing flowers. Of the more than 1300 genera and 33000 species, more than 1300 named taxa of orchids, in 193 genera, grow in Australia. ${ }^{1,2}$

The word "orchid" is from the Greek word orchis (meaning testicle), which reflects the appearance of the root tubers in some species. ${ }^{3}$ According to the "doctrine of signatures" - a 16th century herbalist philosophy which states that herbs resembling body parts can be used to treat those body parts - orchids were used continuously from preliterate times as aphrodisiacs and as medicaments to restore virility. Theophrastus (c. 372288 BC) wrote about the medicinal value of orchids, as did Paracelsus (1491-1541) and Carl Linnaeus (17071778), the father of modern botanical taxonomy. As a child, Linnaeus recorded details of his personally collected orchid specimens in his notebook, in which he wrote "Orchis from testiculus, through which its effects should occur". 4

Orchid extracts such as vanilla (from Vanilla planifolia) $)^{5}$ and salep (from Orchis mascula and Orchis militaria) are used commercially in ice-cream, confectionery and medicinal flavouring agents. ${ }^{6}$ Crawley root preparations (from Corallorhiza odontorhiza) are used in folk medicine for their diaphoretic and antipyretic properties. ${ }^{5}$ In Australia, orchid preparations have been and continue to be used by Indigenous healers to treat diarrhoea and skin infections. ${ }^{7}$ Lieutenant (not yet Captain) James Cook used powdered orchid root as part of his method for preserving the health of his crew. ${ }^{8}$

The physical manifestations of orchids, such as their flowers and the medicines and flavourings derived from them, are ephemeral. But the scientific names of orchids endure, and many perpetuate the lives and works of those who have contributed to medicine since the time of Aristotle. ${ }^{9}$ Here, I describe indigenous orchids of Australia whose scientific names commemorate doctors who worked in Australia, encapsulating a library of Australian medical history. These orchids comprise a monumentum aere perennius (monument more lasting than bronze) - a phrase coined by Horace in Book III of his Odes when referring to his own literary work.

\section{Literature search}

I investigated the origins of the scientific names of Australian orchids by reviewing two parallel and independent resources. The first was a collection of reference texts and journals relating to Australian botany

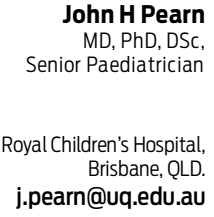

doi: 10.5694/mjal2.10867

These orchids

comprise a

monumentum

aere perennius
- Botanical taxonomy is a repository of medical biographical information. Such botanical memorials include the names of some indigenous orchids of Australia.

- By searching reference texts and journals relating to Australian botany and Australian orchidology, as well as Australian and international medical and botanical biographical texts, I identified 30 orchids indigenous to Australia whose names commemorate doctors and other medical professionals. Of these, 24 have names that commemorate a total of 16 doctors who worked in Australia.

- The doctors and orchids I identified include: doctorsoldiers Richard Sanders Rogers (1862-1942), after whom the Rogers' Greenhood (Pterostylis rogersii) is named, and Robert Brown (1773-1858), after whom the Purple Enamel Orchid (Elythranthera brunonis) is named; navy surgeon Archibald Menzies (1754-1842), after whom the Hare Orchid (Leptoceras menziesii) is named; radiologist Hugo Flecker (1884-1957) after whom the Slender Sphinx Orchid (Cestichis fleckeri) is named; and general medical practitioner Hereward Leighton Kesteven (1881-1964), after whom the Kesteven's Orchid (Dendrobium kestevenii) is named.

- Biographic references in scientific names of plants comprise a select but important library of Australian medical history. Such botanical taxonomy commemorates, in an enduring manner, clinicians who have contributed to biology outside clinical practice.

and Australian orchidology (particularly from a historical perspective). The second was a collection of Australian and international botanical and medical biographical texts, as well as oral history that records details of the lives of doctors for whom there is no published biographical information.

As Australian orchid taxonomy is currently in a state of flux, I report the scientific names given in the Australian Plant Census. ${ }^{2}$ For those not included in this census, I report the names in general use in current orchidology literature. ${ }^{1,10-13}$

\section{Orchids named after medical professionals}

Sixteen doctors who practised medicine and/or botany in Australia have their names recorded in the scientific names of 24 indigenous orchids of Australia (Box). In addition, one separate species (Thelymitra flexuosa, also known as Thelymitra smithiana) and five genera of indigenous Australian orchids record the names of European doctors, pharmacologist-pharmacists or 


\section{Doctors}

Thomas Lane

Bancroft (1860-

1933), son; and Joseph

Bancroft (1836-

1894), father

Hermann Beckler

(1828-1914)

Hans Herman Behr

(1818-1904)

Robert Brown

(1773-1858)

Edwin Daintrey

Hugo Flecker

(1884-1957)

\section{Cestichis fleckeri (= Liparis fleckeri) Thelychiton fleckeri (= Dendrobium fleckeri)}

Arthur George Harrold Habenaria harroldi

(1918-2012)

$\begin{array}{ll}\begin{array}{l}\text { Hereward Leighton } \\ \text { Kesteven (1881-1964) }\end{array} & \text { Dendrobium kestevenii } \\ \begin{array}{ll}\text { Colin Ledward } & \text { Acianthus fornicatus (= Acianthus } \\ \text { (1903-1963) } & \text { ledwardii) }\end{array}\end{array}$

$\begin{array}{ll}\begin{array}{l}\text { Archibald Menzies } \\ (1754-1842)\end{array} & \begin{array}{l}\text { Leptoceras menziesii (= Caladenia } \\ \text { menziesii) }\end{array}\end{array}$

(1754-1842) beckleri); Papillilabium beckleri. known as Golden Cowslips)

Elythranthera brunonis (= Glossodia Prasophyllum brownii

Pterostylis daintreana

\section{Notes}

Thomas Lane Bancroft is one of Australia's greatest doctor-naturalists; he elucidated the

life cycle of the lungfish, Neoceratodus forsteri
(1814-1887)

Arachnorchis behrii; Diuris behrii (also

Ferdinand von Mueller Habenaria ferdinandi; Taeniophyllum (1825-1896) muelleri

$\begin{array}{ll}\begin{array}{l}\text { Charles Brightly } \\ \text { Prentice (1820-1894) }\end{array} & \text { Bulbophyllum prenticei } \\ \begin{array}{l}\text { Richard Sanders } \\ \text { Rogers (1862-1942) }\end{array} & \begin{array}{l}\text { Diplodium rogersii (= Pterostylis } \\ \text { rogersii); Prasophyllum rogersii }\end{array} \\ \begin{array}{l}\text { Daniel Solander } \\ \text { (1733-1782) }\end{array} & \begin{array}{l}\text { Orthoceras strictum (= Orthoceras } \\ \text { solandri) }\end{array} \\ \begin{array}{l}\text { Charles Stanford } \\ \text { Sutton (1865-1950) }\end{array} & \begin{array}{l}\text { Pterostylis suttonii; Prasophyllum } \\ \text { suttonii }\end{array}\end{array}$

herbalists. The five genera are Burnettia Lindl. (described by John Lindley in 1840), a monospecific genus; Cadetia Gaud. (described by Charles Gaudichaud-Beaupré in 1829); Goodyera R.Br. (described by Robert Brown in 1813); Robiquetia Gaud. (described by Charles Gaudichaud-Beaupré in 1829); and Vrydagzynea Blume (described by Carl Ludwig Blume in 1858).

The Lizard Orchid, Burnettia cuneata, blooms in eastern Australia and Tasmania; it commemorates Gilbert Thomas Burnett (1800-1835), surgeon and foundation professor of botany at King's College London. ${ }^{18}$

In the genus Cadetia (delicate white orchids), four species are named after the apothecary of the French imperial court, Charles-Louis Cadet de Gassicourt (1769-
A general medical practitioner in Ipswich and Warwick (Queensland) and, after 1862, in Germany; in 1860, he travelled with the Burke and Wills expedition as a doctor-botanist and expeditioner in Victoria and New South Wales

A physician, botanist, entomologist, lepidopterist, poet, writer, humorist and linguist

A Scottish-born and Edinburgh-trained surgeon, doctor-soldier, and the father of Australian botany; he was awarded the Copley Medal in 1839, then the world's highest accolade in science $^{14}$

A medical student who abandoned his medical career just before graduation; he emigrated to Sydney, where he practised as a solicitor, cofounded the Linnean Society of New South Wales, and was appointed honorary secretary of the Australian Library in Bent Street

A pioneer Australian radiotherapist, radiologist, general medical practitioner and toxicologist of Cairns (Queensland) who dug his own radioactive ore at Radium Hill (South Australia), a medical graduate from the University of Sydney, and a natural historian; his life and works are commemorated by the Flecker Botanic Gardens in Cairns

A navy surgeon who later worked as general medical practitioner, ecologist and conservationist in Noosa (Queensland), and graduate of the University of Cambridge; he formed the Noosa Parks Association in 1962 and helped establish the Cooloola National Park

A general medical practitioner, medical scientist, zoologist, pioneer of industrial medicine in Australia, and national medical director of the Allied Works Council during World War II

A general medical practitioner of Cloncurry and Canungra (Queensland); the orchid that bears his name was collected from a single colony discovered in 1934 and is now almost certainly extinct

A British navy surgeon who circumnavigated the globe from west to east with Captain George Vancouver, in the tumultuous voyage of 1791 to 1794, explored extensively in southwest Western Australia, and was later president of the Linnean Society of London; his name is recorded in the names of banksias (including the Firewood Banksia [Banksia menziesii]), orchids and mosses of the King George Sound hinterland, which record his service to Australian botany ${ }^{15}$

A qualified pharmacist in Rostock (Germany) who emigrated to Australia in 1847 and wrote extensively on the medicinal properties of plants; he was a founder of Australian botany and published over 800 articles on botany

A Brisbane surgeon, naturalist and botanical collector; a member of the Medical Board of Queensland; and an expert on Australian ferns

An Adelaide physician, doctor-soldier and forensic pathologist who described 82 new orchid species (66 from Australia)

A medical student in Sweden and London, and botanist-librarian on the Endeavour voyage to Australia (1769-1771); his name is commemorated in the names of Australian species of Acacia, Banksia and Geranium ${ }^{16}$

A Melbourne general medical practitioner and expert on subalpine flora ${ }^{17}$ 


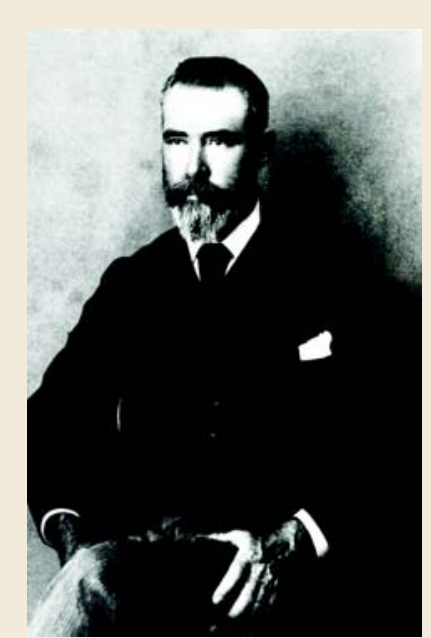

Thomas Lane Bancroft (image courtesy of the Australian Medical Association of Queensland).
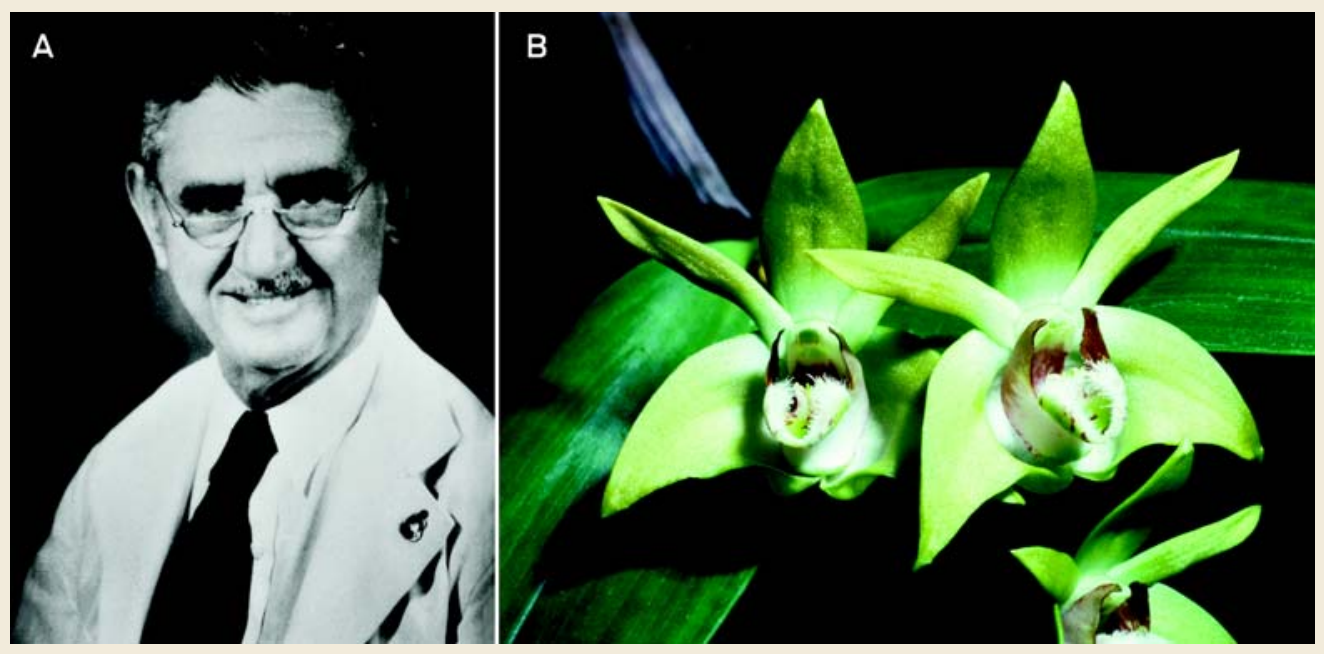

A: Hugo Flecker (image courtesy of Patrick Flecker). B: Flecker's Dendrobium (or Apricot Cane Orchid), Thelychiton fleckeri (image courtesy of Ted Gregory).
Daintree rainforest in north Queensland, it commemorates Theodore Daniel Vrydag Zynen (fl. 1850), a Dutch pharmacologist and contemporary of one of the most famous doctor-orchidologists, Karl Ludwig Blume (1796-1862). ${ }^{21}$

The Twisted Sun Orchid, Thelymitra flexuosa, commemorates the Norwich physician and friend of Joseph Banks, Sir James Edward Smith (1759-1828). When he was 25 years old, Smith took the decisive action to buy the great Linnean collection of plants, which were in danger of being lost to science following the death of Linnaeus's son in 1783. Smith bought them when they were offered for sale in $1784 .^{22}$ In conjunction with the bishop of Carlisle, he founded the Linnaean Society of London and was its first president. In 1798, he raised the new genus, Diuris, which is one of the first taxa of Pacific orchids to be described. The Lilly Pilly, Syzygium smithii, is another of his six botanical memorials.

\section{Early orchidology in the Asia-Pacific region}

The fleshy pseudobulbs (thickened stems that serve as storage organs) of orchids have been eaten and used medicinally by Indigenous Australians for thousands of years. ${ }^{7}$ The first Australian orchids brought to the attention of Western science were three species of Dendrobium ( $D$. discolor Lindley [described by John Lindley]; $D$. canaliculatum R.Br. [described by Robert Brown]; and D. rigidum R.Br. [described by Robert Brown]) that were collected by Joseph Banks and Daniel Solander at the Endeavour River between 17 June and 3 August 1770. ${ }^{16}$ Solander had trained in medicine and botany under Linnaeus in Uppsala (Sweden) and, after 1759, in London (England). One of the plant species named after him is the Australian orchid Orthoceras solandri (also known as Orthoceras strictum).

The first orchids scientifically named in the Pacific were species in the genus Thelymitra J.R.Forst. \& G.Forst., a taxon raised and coined by the Forsters - the irascible

Johann Reinhold Forster (1729-1798), and his son Georg Forster (1754-1794), who was 18 years old when they left on Cook's second voyage of 1772 to $1775 .{ }^{23}$ The Forsters collected Thelymitra longifolia in the South Island of New Zealand in 1772 and published the name of the species in 1776. The Forsters described and named nine new species in what they termed the "Class of Orches" in the South Pacific. ${ }^{24}$ Georg Forster graduated in medicine in Vilna (now Vilnius, Lithuania) in 1784. Species of Thelymitra, which are known as the Sun Orchids, are found mainly in the south-west of Western Australia. ${ }^{23}$

Brown also described the movement of microscopic grains from pollen cells on the surface of water, a phenomenon now called Brownian motion

\section{Notable doctor-botanists of Australia}

\section{Robert Brown}

Robert Brown, the father of Australian botany, named more species of Australian orchids than any other botanist. ${ }^{14}$ His reputation as a botanist has tended to overshadow the details of his medical life. Until he was 28 years old, he served as an English military surgeon. While serving as a doctor-soldier in the Fifeshire Fencibles, he used his medical training to study plants. He circumnavigated Australia with Matthew Flinders on the HMS Investigator (1801-1803) during his 3.5 years in Australian waters. In WA, Brown collected 500 new species. He eventually documented 2000 new Australian botanical species, on top of some 33000 species known from the entire world at the time. ${ }^{25}$ Among these, he described 120 new Australian species of orchids. In 1810, he published the first volume of his Prodromus florae Novae Hollandiae et insulae van-Diemen, described by another former naval surgeon-botanist, Sir William Hooker, as the greatest botanical work ever. ${ }^{26}$ It listed 464 genera, a third of them for the first time, and three-quarters of the named species were new to science. Brown also described the movement of microscopic grains from pollen cells on the surface of water, a phenomenon now called Brownian motion. ${ }^{27}$ Although his death was unnoticed and unrecorded in Australia, three native orchids (Box) endure 
as his living memorials. ${ }^{15}$ One of these is the Purple Enamel Orchid (Elythranthera brunonis).

\section{Richard Sanders Rogers}

Richard Sanders Rogers was a senior physician and forensic pathologist and an acknowledged international authority on orchids of Australasia. He served as honorary physician at the Adelaide Hospital (18971909) and as a member of the Medical Board of South Australia (1910-1940). He also served with distinction as the commanding officer of the 7th Australian General Hospital during World War I. ${ }^{28}$ He published 29 scientific articles on orchids of Australia and named 82 new species. His many publications include his book $A n$ introduction to the study of South Australian orchids, published in 1909, and the section on Orchidaceae in John McConnell Black's book Flora of South Australia, published in 1922. Two orchids bear his name (Box) - one is Rogers' Greenhood (Pterostylis rogersii), also known as the Curled-tongue Shell Orchid.

\section{Charles Stanford Sutton}

Charles Stanford Sutton was a general medical practitioner. He was an active member of the Field Naturalists' Club of Victoria from 1900 to 1950), its president from 1915 to 1916, and its librarian from 1924 to 1943 . His major publications include three articles in The Victorian Naturalist - "Among the alpine flowers" (1903), "A botanical collector in the Mallee" (1906) and "A botanist at Mount Buller" (1907) — and his books A sketch of the Keilor Plains flora (1916) and Cradle Mountain (Tasmania) and its flora (1923). Sutton was a subalpine specialist and accordingly his name is commemorated in the Alpine Leek-orchid, Prasophyllum suttonii, collected on an expedition he led to Mount Buffalo in December 1902. ${ }^{17}$
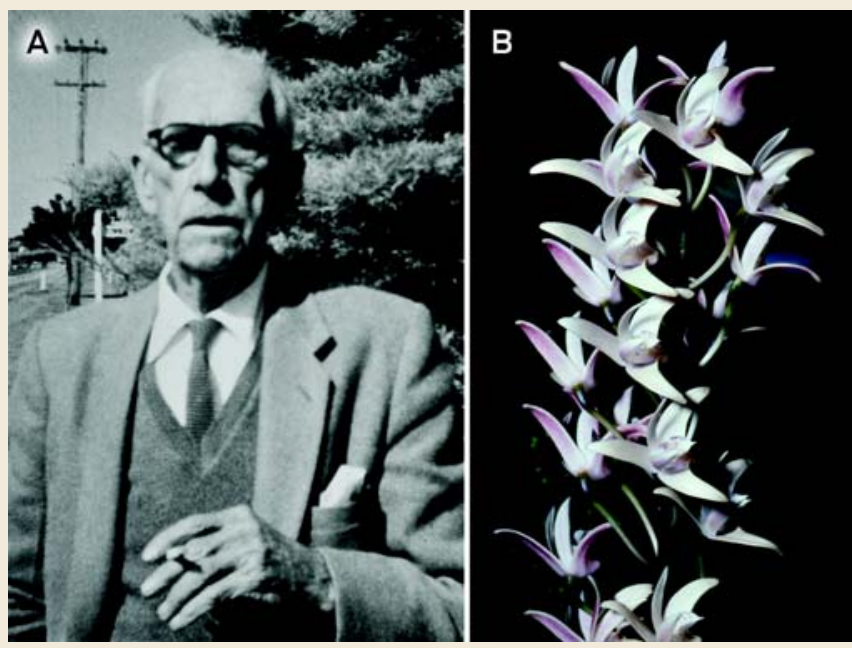

A: Hereward Leighton Kesteven. B: Kesteven's Orchid, Dendrobium kestervenii (image courtesy of Ted Gregory).
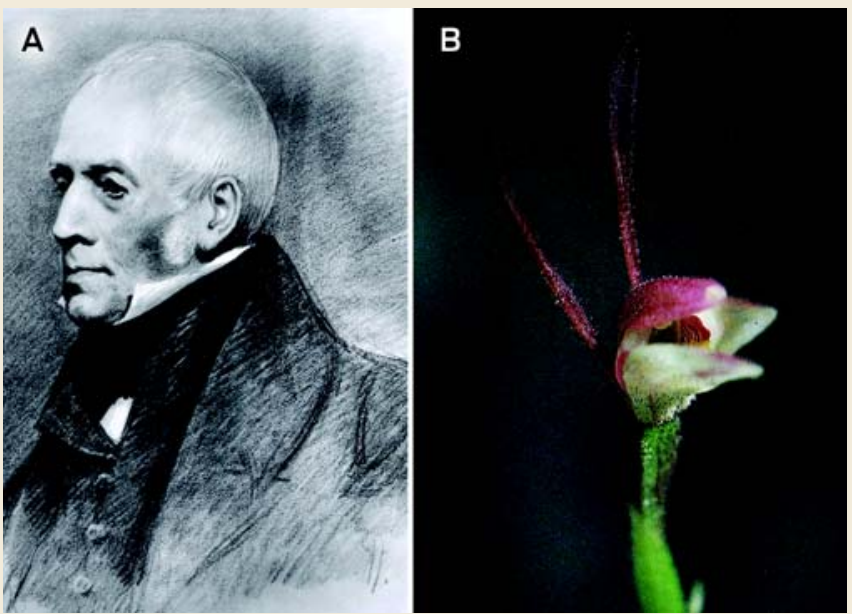

A: Archibald Menzies (image courtesy of the Hunt Institute for Botanical Documentation). B: The Hare Orchid (or Rabbit Orchid), Caladenia menziesii (image courtesy of Murray Fagg).
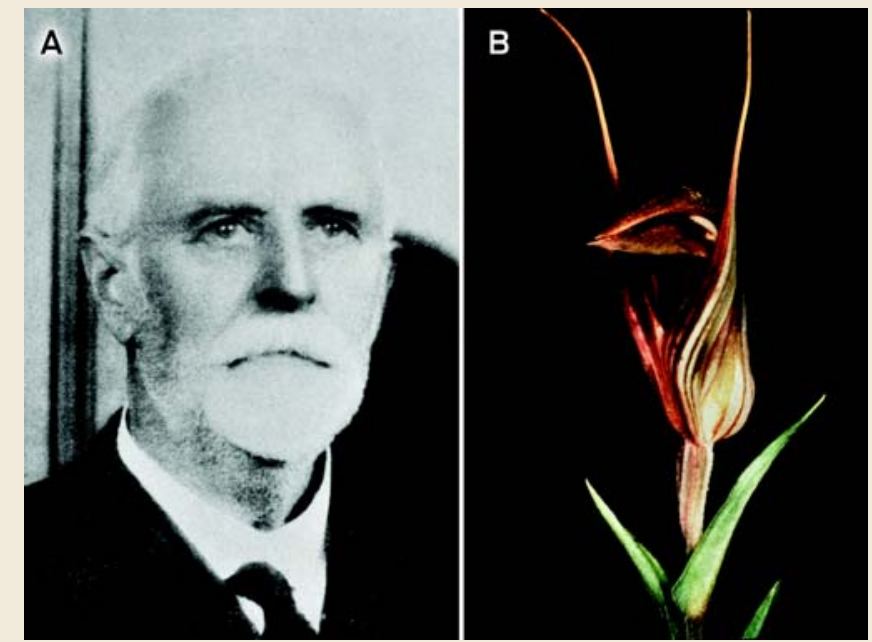

A: Richard Sanders Rogers. B: Rogers' Greenhood (or Curled-tongue Shell Orchid), Pterostylis rogersii (image courtesy of Murray Fagg).

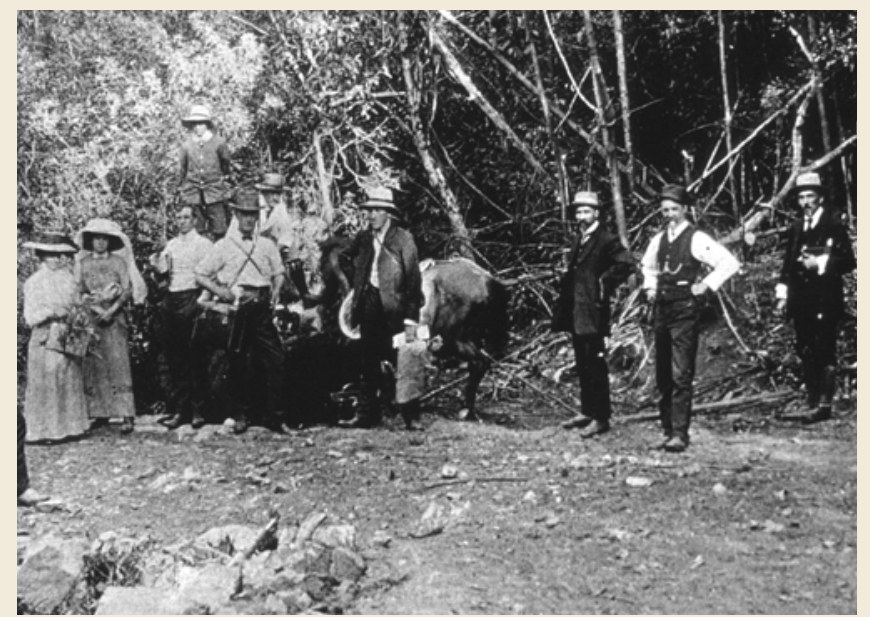

Charles Stanford Sutton (far right) as a leader of a botanical excursion of the Field Naturalists Club of Victoria at Myers Creek, in the Healesville district of Victoria, on 25 November 1911. 


\section{Hans Herman Behr}

The German-born doctor-expeditioner Hans Herman Behr was appointed professor of botany at the California College of Pharmacy in San Francisco in 1850. He explored the Barossa Valley and Mount Lofty Ranges and, in 1851, published an article titled "On the character of the South Australian flora in general". Two Australian orchids bear his name (Box) - one is called the Lofty Ranges Spider Orchid (Arachnorchis behrii).

\section{Hugo Flecker}

Hugo Flecker, a pioneering Australian radiologist radiotherapist and active member of the Field Naturalists' Club of Victoria from $1921,{ }^{29}$ is commemorated in the names of eight botanical species and the name of the Australian box jellyfish (Chironex fleckeri). This memorial is balanced by the names of two beautiful epiphytic orchids - the rare Apricot Cane Orchid, Thelychiton fleckeri, which grows in the cloud and mist forests on Mount Finnigan and Mount Fisher in Cape York, and the Slender Sphinx Orchid, Cestichis fleckeri.

\section{Enduring memorials}

Scientific names of living things will be used as long as scientists find it useful to do so. Names change as taxonomists revise plant groupings and there is a proposal to dispense with scientific names, in favour of an alternative system called the PhyloCode. In the past, the doctrine of signatures linked the forms of plants with their supposed therapeutic uses. But the world of binomial nomenclature (which Linnaeus introduced in 1753), allows for the most fitting memorials in medicine and botany. In the scientific names of Australian orchids, the lives of many doctors and botanists endure.

\section{Competing interests: No relevant disclosures.}

1 Jones DL. A complete guide to native orchids of Australia: including the Island Territories. Sydney: Reed New Holland, 2006: 12, 78-79.

2 Council of Heads of Australasian Herbaria. Australian plant census. Orchidaceae. http://www.anbg.gov.au/chah/apc/family-translation/ brummitt-APC-gen.html (accessed Aug 2012).

3 Bulpitt CJ. The uses and misuses of orchids in medicine. QJM 2005; 98 : 625-631.

4 Landell N-E. Doctor Carl Linnaeus, physician. Hansen L, editor. Mazzarella S, translator. London: IK Foundation, 2008: 44.

5 Wren RC. Potter's new cyclopaedia of botanical drugs and preparations. 7th ed. Re-edited and enlarged by RW Wren. Rustington, UK: Health Science Press, 1968: 101.
6 Hossain MM. Therapeutic orchids: traditional uses and recent advances - an overview. Filoterapia 2011; 82: 102-140.

7 Pearn J. The world's longest surviving paediatric practices: some themes of Aboriginal medical ethnobotany in Australia. J Paediatr Child Health 2005; 41: 284-290.

8 Cook J. The method taken for preserving the health of the crew of His Majesty's ship the Resolution during her late voyage round the world. Phil Trans R Soc Lond 1776; 66: 402-406. doi: 10.1098/rstl.1776.0023.

9 Pearn J. A doctor in the garden: Australian flora and the world of medicine. Brisbane: Amphion Press, 2001: 2-12.

10 Baines JA. Australian plant genera. Sydney: Society for Growing Australian Plants, 1981.

11 Chapman AD. Australian plant name index. Canberra: Australian Government Printing Service, 1991.

12 Royal Botanic Gardens Kew. Orchid research newsletter. http:// www.rbgkew.org.uk/herbarium/orchid (accessed Nov 2012).

13 Brown A, Dundas P, Dixon K, Hopper S. Orchids of Western Australia. Perth: University of Western Australia Press, 2008.

14 Mabberley DJ. Jupiter botanicus: Robert Brown of the British Museum. Braunschweig: J Cramer, 1985.

15 Balfour FRS. Archibald Menzies, 1754-1842, botanist, zoologist, medico and explorer. Proc Linn Soc Lond 1945; 156: 170-183. doi: 10.1111/j.10958312.1945.tb00390.x

16 Nature's Powerhouse, Cooktown Botanic Gardens. Joseph Banks and Daniel Solander. http://www.naturespowerhouse.com.au/banks_list.htm (accessed Feb 2012).

17 Nicholls WH. Our rarer orchids. 8. Prasophyllum suttonii. Victorian Nat 1933; 50: 69-71.

18 Lucas AM. Burnett, Gilbert Thomas (1800-1835), surgeon and botanist. In: Oxford dictionary of national biography. Online edition. Oxford: Oxford University Press, 2008. http://www.oxforddnb.com/index/101004073/GilbertBurnett (accessed Feb 2012; subscription required).

19 Bourgoin E, editor. La grande encyclopédie. Vol VIII. Paris: Brice-Canarie, s.d.: 694.

20 Warolin C. Pierre Jean Robiquet [French]. Rev Hist Pharm (Paris) 1999; 47: 97-110.

21 Blume KL. Vrydagzynea. Orch Arch Ind 1858; 71: 17-20.

22 Wittrock VB. Smith, Sir James Edward. Acta Horti Bergiani 1905; 3: 82-83.

23 Heberle RL. Thelymitra "the sun orchids" of south western Australia - the genus. Proceedings of the 12th Australian Orchid Consortium; 1991; Perth. http://members.iinet.net.au/ emntee/Thelymitras\%20Page\%20250.htm (accessed Feb 2012).

24 Nicolson DH, Fosberg FR. The Forsters and the botany of the second Cook expedition (1772-1775). 2nd ed. Liechtenstein: ARG Gantner, 2004: 205-218.

25 Balfour JH. Biographical sketch of the late Robert Brown. Trans Bot Soc Edinburgh 1858; 6: 119-128.

26 Brown R. Prodromus florae Novae Hollandiae et insulae van-Diemen, 1810. Supplementum primum, 1830. With Introduction by WT Steam. In Historiae naturalis classica Vol 6. Weinheim: JR Engelmann, 1960.

27 Brown R. A brief account of microscopic observations made on the particles contained in the pollen of plants. Phil Mag Lond 1828; 4:161-173.

28 Sims EB. Rogers, Richard Sanders. In: McDonald GC, editor. Roll of the Royal Australasian College of Physicians. Vol I: 1938-1975. Sydney: Royal Australasian College of Physicians, 1988: 249-251.

29 Pearn JH. Flecker, Hugo (1884-1957). In: Nolan M, editor. Australian Dictionary of Biography. Canberra: National Centre of Biography, Australian National University, 2012. http://adb.anu.edu.au/biography/flecker-hugo-10199 (accessed Nov 2012). 